\title{
Therapeutic value of frankincense and myrrh In liver recovery after exposure to aflatoxin $b_{1}$
}

\author{
Taha A. Kumosani* , Jehad M. Yousif ${ }^{* *}$ and Omayma A. Abou Zeid** \\ *Biochemistry Department, Faculty of Science, King Abdulaziz University; \\ ${ }^{* *}$ Chemistry Department, Faculty of Science, Girl's Collage of Education, \\ Jeddah, Saudi Arabia
}

\begin{abstract}
Frankincense, (Gum Olibanum), and Myrrh, (Commiphora merrha), are of plant resins produce by the Burseraceae family, growing in Somali, India and Yemen. They were known for thousands of years as one of hoarding in the east. In order to study the therapeutic value of such resins on liver recovery after exposure to aflatoxin $B_{1}$, it was administrated intra- peritoneal to male Wister Albino rats for 10 days, after which Frankincense and Myrrh, (each one alone), were given in the form of water extract to rats for 20 days. At the end of the study blood from all experimental animals was analyzed for some biochemical parameters including glucose, triglycerides, cholesterol, urea, uric acid, creatinine, bilirubin, hemoglobin and some key liver enzymes as asparate amino transferase (AST), alanine amino transferase (ALT), gamma- glutamyl transferase (GGT). Liver tissue samples were analysed for their content of total proteins, deoxyribonucleic acid (DNA), ribonucleic acid (RNA) and in addition to histopathological examination. This study demonstrated that Frankincense and Myrrh are of certain therapeutic recovery value in liver after exposure to $A F B_{1}$.
\end{abstract}

\section{INTRODUCTION}

Today, one of the most urgent problems of public health is the development of effective methods to block the environmental carcinogenesis sequential events. Liver cancer (Primary hepatocellular carcinoma), is a major public health hazard in the developing countries of Africa and Asia. The etiology of this disease implicates both infection with hepatitis $\mathrm{B}$ and $\mathrm{C}$ and exposure to aflatoxin $\mathrm{B}_{1},\left(\mathrm{AFB}_{1}\right)$, as a food contaminant, (Montalto et al., 2002) ${ }^{\mathbf{1}}$.

Chemoprevention is a concept defined as prevention of cancer by the administration of natural or synthetic pure chemicals, or through daily foods rich in cancer preventive components. Several compounds have been discovered with inhibitory effects on the tumor-promoting stage, interestingly many of them were derived from plants, (Vimala et al., 1999 and Borrelli \& Izzo, 2000) $)^{\mathbf{2 , 3}}$. However, primary cancer prevention has two aspects in its methodology; exclusion or avoidance of the environmental carcinogens and other chemical factors closely related to carcinogenesis such as tumor promoters; and the administration of inhibitory or suppressive agents 
against carcinogenesis (Elegbede et al., 2002) ${ }^{4}$.

Both Frankincense, (Gum Olibanum) and Myrrh, (Commiphora merrha), of the botanical family Burseraceae are resins from small trees or shrubs. Their natural abundance is limited, but this has been overcome by systematic regular cultivation to meet world wide demands. Today, most Frankincense and Myrrh are produced in the Southern Arabian Peninsula, (Oman and Yemen) and in southeast Africa, (Somalia). When referring to this pair of herbs, western people might immediately think of their historic importance in religion, (Hostanska et al., 2002) ${ }^{5}$.

The resins obtained from different plants have long been known in the traditional medicine of different countries. The main components of Frankincense are alpha-pinene, boswellic acid together with many other compounds, (Hostanska et al., 2002 and Shi et al., 2002) ${ }^{5,6}$. As a treatment it was used as antiinflammatory, anti-proliferative toward a variety of malignant cells and in the treatment of non-insulin dependent diabetes mellitus, (Al-wadi et al., 1991, Liu et al., 2002 and Park et al., 2002) $)^{7,8,9}$.

The chemical composition of resin Myrrh which is obtained from the stem of different commiphor species is sesquiterpenoids, volatile oils and many active component, (Zhu et al., 2001 and El Ashry et al., $2003)^{10,11}$. It is highly reputed and commonly used in Arab medicine as anti-inflammatory, anti- ulcer, antithrombotic, anti-pyretic, anti-septic, for lowering serum cholesterol and triglycerides, inhibiting cholera toxin, anti-microbial and fascioliasis. When medicinally tested in a variety of diseases it caused a decrease in the contents of nucleic acids and proteins, (Tariq et al., 1986; Michie \& Cooper, 1991, Al-Harbi et al., 1997, Olajide, 1999 and Massoud et al., 2000) ${ }^{\mathbf{1 2 - 1 6}}$. The aim of this research is to study the therapeutic value of Frankincense and Myrrh extracts in the recovery of liver after exposure to aflatoxin $\mathrm{B}_{1}$.

\section{MATERIAL \& METHODS}

\section{Animals}

In this study, 84 Male Wister Albino Rats, weighing 70-100 gm were kept on commercial laboratory standard diet. The rats were divided into 4 groups of 21 rats each. With the exception of the normal control group, all groups were injected i.p with $20 \mu \mathrm{l}$ of $0.1 \mathrm{ml} / 100 \mathrm{gm}$ body weight aflatoxin $\mathrm{B}_{1}$, solution, once a day for 10 days, (Qin et al., 1997) ${ }^{\mathbf{1 7}}$. After 10 days of aflatoxin $B_{1}$ injection one group was left without treatment and served as $\mathrm{AFB}_{1}$ non- treated group. The other two groups namely; the Frankincense treated and the Myrrh treated groups were allowed to drink the respective resin extracts adlibitum.

\section{Methods}

Resins extracts were prepared by stirring of $20 \mathrm{gm}$ of the resin in 400 $\mathrm{ml}$ distilled water for $60 \mathrm{~min}$ at $80^{\circ} \mathrm{C}$, after which the extract was cooled to room temperature, filtered and administered to the animals in drinking bottles, (Zhou et al. 2000) ${ }^{\mathbf{1 8}}$.

On day 20 of treatment, blood samples were withdrawn from all animals for the determination of 
serum enzymes; aspartate aminotransferase, AST, (Saris, 1978) ${ }^{\mathbf{1 9}}$, alanine aminotransferase, ALT, (Bergmeyr et al., 1978) ${ }^{\mathbf{2 0}}$ and gama glutamyl aminotransferase, GGT, (Shaw et al., 1983) ${ }^{21}$. Other analysis included: bilirubin, (Jendrassik \& Grof, 1938) ${ }^{22}$, urea, (Talke \& Schubert, 1965) ${ }^{23}$, uric acid, (Bulgar \& Johns, 1941) ${ }^{24}$, creatinine, (Larsen, 1972) ${ }^{25}$, cholesterol, (Stadtman, 1957) ${ }^{\mathbf{2 6}}$, triacylglycerols, (Rautela et al., 1974) ${ }^{27}$, glucose, (Henry, 1974) 28, hemoglobin, (Van Assendelf, 1970 $)^{\mathbf{2 9}}$. Liver tissue samples from each group were obtained for the determination of RNA, DNA, (Bregman, 1983) ${ }^{30}$ and total protein, (Lowry et al., 1951) ${ }^{31}$. Histopathological examination was Performed according to Bancroft \& Steven, $1996^{32}$.

\section{Statistical analysis}

Data were statistically analyzed using the student t-test with SPSS program version 13.

\section{RESULTS}

Results of biochemical analysis are shown in table (1), while those of liver tissue analysis are shown in table (2), followed by the results of histological examination of liver tissue.

It is clear form table (1) that there have been a statistically very highly significant increase in serum GGT, bilirubin and glucose, $(\mathrm{p}<0.0001)$ in the $\mathrm{AFB}_{1}$ non-treated group, accompanied by a statistically very highly significant decrease in serum cholesterol and triglycerides, $(\mathrm{p}<0.0001)$, as compared to the normal control group, (t-1) with statistically non-significant changes in all other measured parameters.

With Frankincense, a notable statistically significant decrease in serum bilirubin and an increase of cholesterol to the normal levels are found. Serum uric acid, however, appears on increase, $(\mathrm{p}<0.05)$ over its normal level, while blood hemoglobin continues to decrease to reach a statistically significant, $\quad(\mathrm{p}<0.005)$ lower value. This picture changed a little on treatment with Myrrh, as serum AST and urea appear to be statistically increased, $(\mathrm{p}<0.05)$. The same applies for serum GGT, with the return of serum uric acid and glucose to their normal vales.

On comparison with $\mathrm{AFB}_{1}$ nontreated group, (t-2), treatment with Frankincense statistically decreased serum bilirubin and blood hemoglobin significantly, $(\mathrm{p}<0.05)$ and serum triglycerides very highly significantly, $(\mathrm{p}<0.0001)$ with a notable increase in serum cholesterol, $(\mathrm{p}<0.0001)$.

With Myrrh treatment, serum AST remains higher, $(\mathrm{p}<0.01)$ with statistically significantly lower serum bilirubin, $(p<0.001)$, urea, $(p<0.05)$, glucose, $\quad(p<0.0005)$ and blood hemoglobin, $(\mathrm{p}<0.05)$.

On statistical comparison of treatment with Frankincense and Myrrh, (t-3) non-significant differences were found in serum AST, ALT, bilirubin, creatinine and blood hemoglobin, while serum urea, uric acid, cholesterol and glucose were statistically lower and triglycerides higher in the Myrrh treated over the Frankincense treated group, $(\mathrm{p}<0.05-\mathrm{p}<0.0001)$. 
Table (1): Mean \pm SEM and t-test* of Biochemical Parameters.

\begin{tabular}{|c|c|c|c|c|}
\hline Group & $\begin{array}{l}\text { Normal Control } \\
\text { Group }\end{array}$ & $\begin{array}{l}\text { AFB }_{1} \\
\text { Non-treated } \\
\text { Group } \\
\end{array}$ & $\begin{array}{l}\text { AFB }_{1} \\
\text { Frankincense } \\
\text { Treated Group }\end{array}$ & $\begin{array}{l}\text { AFB }_{1} \\
\text { Myrrh Treated } \\
\text { Group }\end{array}$ \\
\hline $\begin{array}{l}\text { AST (U/L) } \\
t-1 \\
t-2 \\
t-3\end{array}$ & $259.9 \pm 41.5$ & $\begin{array}{l}242.3 \pm 43.7 \\
\text { N.S. }\end{array}$ & $\begin{array}{l}227.3 \pm 142.2 \\
\text { N.S. } \\
\text { N.S. }\end{array}$ & $\begin{array}{l}425 \pm 56.8 \\
p<0.05 \\
p<0.01 \\
\text { N.S }\end{array}$ \\
\hline $\begin{array}{l}\mathrm{ALT}(\mathrm{U} / \mathrm{L}) \\
\mathrm{t}-1 \\
\mathrm{t}-2 \\
\mathrm{t}-3\end{array}$ & $88.8 \pm 20.2$ & $\begin{array}{l}66.5 \pm 11.1 \\
\text { N.S. }\end{array}$ & $\begin{array}{l}120 \pm 49.2 \\
\text { N.S. } \\
\text { N.S. }\end{array}$ & $\begin{array}{l}79.3 \pm 11.6 \\
\text { N.S } \\
\text { N.S. } \\
\text { N.S. }\end{array}$ \\
\hline $\begin{array}{l}\text { GGT (U/L) } \\
\text { t-1 } \\
\mathrm{t}-2 \\
\mathrm{t}-3\end{array}$ & $10 \pm 0.76$ & $\begin{array}{l}13.6 \pm 0.34 \\
p<0.0001\end{array}$ & $\begin{array}{l}15 \pm 5.8 \\
\text { N.S. } \\
\text { N.S. }\end{array}$ & $\begin{array}{l}14.2 \pm 0.6 \\
\text { p }<0.0001 \\
\text { N.S. } \\
\text { N.S. }\end{array}$ \\
\hline $\begin{array}{l}\text { Bilirubin (mg/dl) } \\
\mathrm{t}-1 \\
\mathrm{t}-2 \\
\mathrm{t}-3\end{array}$ & $0.17 \pm 0.2$ & $\begin{array}{l}1.26 \pm 0.15 \\
p<0.0001\end{array}$ & $\begin{array}{l}0.25 \pm 0.46 \\
\text { N.S. } \\
p<0.05\end{array}$ & $\begin{array}{l}0.41 \pm 0.19 \\
\text { N.S. } \\
\text { p }<0.001 \\
\text { N.S. }\end{array}$ \\
\hline $\begin{array}{l}\text { Urea ( mg/dl) } \\
\text { t-1 } \\
\text { t-2 } \\
\text { t-3 }\end{array}$ & $26.3 \pm 1.03$ & $\begin{array}{l}24.9 \pm 1.05 \\
\text { N.S. }\end{array}$ & $\begin{array}{l}27.6 \pm 1.5 \\
\text { N.S. } \\
\text { N.S. }\end{array}$ & $\begin{array}{l}21.5 \pm 1.7 \\
p<0.05 \\
p<0.05 \\
p<0.01\end{array}$ \\
\hline $\begin{array}{l}\text { Uric acid (mg/dl) } \\
\text { t-1 } \\
\text { t-2 } \\
\text { t-3 }\end{array}$ & $2.2 \pm 0.3$ & $\begin{array}{l}3.11 \pm 0.5 \\
\text { N.S. }\end{array}$ & $\begin{array}{l}3.8 \pm 0.63 \\
\mathrm{p}<0.05 \\
\text { N.S. }\end{array}$ & $\begin{array}{l}2.1 \pm 0.76 \\
\text { N.S. } \\
\text { N.S. } \\
p<0.05\end{array}$ \\
\hline $\begin{array}{l}\text { Creatinine (mg/dl) } \\
\mathrm{t}-1 \\
\mathrm{t}-2 \\
\mathrm{t}-3\end{array}$ & $0.3 \pm 0.27$ & $\begin{array}{l}0.4 \pm 0.24 \\
\text { N.S. }\end{array}$ & $\begin{array}{l}0.33 \pm 0.42 \\
\text { N.S. } \\
\text { N.S. }\end{array}$ & $\begin{array}{l}0.38 \pm 0.2 \\
\text { N.S. } \\
\text { N.S. } \\
\text { N.S. }\end{array}$ \\
\hline $\begin{array}{l}\text { Cholesterol (mg/dl) } \\
\mathrm{t}-1 \\
\mathrm{t}-2 \\
\mathrm{t}-3\end{array}$ & $115.5 \pm 2.9$ & $\begin{array}{l}65.3 \pm 2.5 \\
p<0.0001\end{array}$ & $\begin{array}{l}121.3 \pm 5.2 \\
\text { N.S. } \\
p<0.0001\end{array}$ & $\begin{array}{l}59.8 \pm 0.9 \\
p<0.0001 \\
\text { N.S. } \\
p<0.0001\end{array}$ \\
\hline $\begin{array}{l}\text { Triglycerides (mg/dl) } \\
\mathrm{t}-1 \\
\mathrm{t}-2 \\
\mathrm{t}-3\end{array}$ & $149.9 \pm 6.2$ & $\begin{array}{l}66.4 \pm 2.1 \\
p<0.0001\end{array}$ & $\begin{array}{l}39.1 \pm 5.2 \\
p<0.0001 \\
p<0.0001\end{array}$ & $\begin{array}{l}74.2 \pm 8.99 \\
p<0.0001 \\
\text { N.S. } \\
p<0.001\end{array}$ \\
\hline $\begin{array}{l}\text { Glucose (mg/dl) } \\
\mathrm{t}-1 \\
\mathrm{t}-2 \\
\mathrm{t}-3\end{array}$ & $134.5 \pm 4.6$ & $\begin{array}{l}168.5 \pm 5.3 \\
p<0.0001\end{array}$ & $\begin{array}{l}202 \pm 14.6 \\
p<0.0001 \\
\text { N.S. }\end{array}$ & $\begin{array}{l}134.5 \pm 10.3 \\
\text { N.S. } \\
p<0.005 \\
p<0.0005\end{array}$ \\
\hline $\begin{array}{l}\text { Hemoglobin (mmol/L) } \\
\mathrm{t}-1 \\
\mathrm{t}-2 \\
\mathrm{t}-3\end{array}$ & $10.5 \pm 0.7$ & $\begin{array}{l}9.4 \pm 0.41 \\
\text { N.S. }\end{array}$ & $\begin{array}{l}8.2 \pm 0.43 \\
p<0.005 \\
p<0.05\end{array}$ & $\begin{array}{l}7.9 \pm 0.77 \\
p<0.01 \\
p<0.05 \\
\text { N.S. }\end{array}$ \\
\hline
\end{tabular}

$*$ t-test: $t-1=$ v.s. Normal control group.

$t-2=v . s . A F B 1$ non-treated group.

$t-3=$ v.s. $A F B_{1}$ Frankincens treated group. 
Table (2), shows the results of liver tissue analysis of the four experimental groups, viz. total proteins, RNA and DNA. It was found that $\mathrm{AFB}_{1}$ injection had caused a statistically significant, (t-1) decrease in liver total protein content, $(\mathrm{p}<$ 0.05 ) together with non-significant decrease of both RNA and DNA, as compared to the normal control group.

Treatment with Frankincense showed a non-significant increase in all measured parameters, while treatment with Myrrh showed statistically significant increase in total protein, $(\mathrm{p}<0.005)$ and DNA, $(\mathrm{p}$
$<0.05)$ in comparison to the normal control group. However, there has been a statistically non-significant increase, (t-2) in all measured parameters in the Frankincense treated group on comparison to the $\mathrm{AFB}_{1}$ non-treated group, while only a highly significant increase in total protein was observed in the Myrrh treated group on the same comparison. Neither Frankincense nor Myrrh showed any statistically significant difference, (t-3) between each other in their effects on the concerned parameters.

Table (2): Mean \pm SEM and t-test* of liver Total Proteins, RNA, DNA, ratio of RNA/ DNA \% and Ratio of RNA and DNA to Total Protein \%.

\begin{tabular}{|c|c|c|c|c|}
\hline Group & $\begin{array}{l}\text { Normal } \\
\text { Control } \\
\text { Group }\end{array}$ & $\begin{array}{l}\text { AFB }_{1} \\
\text { Non-treated } \\
\text { Group }\end{array}$ & $\begin{array}{l}\text { AFB }_{1} \\
\text { Frankincense } \\
\text { Treated Group }\end{array}$ & $\begin{array}{l}\text { AFB }_{1} \\
\text { Myrrh Treated } \\
\text { Group }\end{array}$ \\
\hline $\begin{array}{l}\text { Total protein (gm/100gm) } \\
\mathrm{t}-1 \\
\mathrm{t}-2 \\
\mathrm{t}-3\end{array}$ & $\begin{array}{ll}6.84 & \pm \\
0.39 & \end{array}$ & $\begin{array}{l}5.54 \pm 0.85 \\
p<0.05\end{array}$ & $\begin{array}{l}7.24 \pm 1.77 \\
\text { N.S. } \\
\text { N.S. }\end{array}$ & $\begin{array}{l}8.6 \pm 0.38 \\
p<0.005 \\
p<0.005 \\
\text { N.S. }\end{array}$ \\
\hline $\begin{array}{l}\text { RNA (gm/100gm) } \\
\mathrm{t}-1 \\
\mathrm{t}-2 \\
\mathrm{t}-3\end{array}$ & $\begin{array}{l}2.06 \quad \pm \\
0.40\end{array}$ & $\begin{array}{l}1.29 \pm 0.52 \\
\text { N.S. }\end{array}$ & $\begin{array}{l}2.19 \pm 0.14 \\
\text { N.S. } \\
\text { N.S. }\end{array}$ & $\begin{array}{l}2.15 \pm 0.18 \\
\text { N.S. } \\
\text { N.S. } \\
\text { N.S. }\end{array}$ \\
\hline RNA/Total Protein \% & 30.12 & 23.29 & 30.25 & 25.00 \\
\hline $\begin{array}{l}\text { DNA (gm/100gm) } \\
\text { t-1 } \\
\text { t-2 } \\
\text { t-3 }\end{array}$ & $\begin{array}{l}0.75 \\
0.34\end{array}$ & $\begin{array}{l}0.47 \pm 0.69 \\
\text { N.S. }\end{array}$ & $\begin{array}{l}1.44 \pm 0.98 \\
\text { N.S. } \\
\text { N.S. }\end{array}$ & $\begin{array}{l}1.55 \pm 0.15 \\
p<0.05 \\
\text { N.S. } \\
\text { N.S. }\end{array}$ \\
\hline DNA/Total Protein \% & 10.96 & 8.43 & 19.89 & 18.02 \\
\hline RNA/DNA \% & 274.7 & 274.5 & 152.1 & 138.7 \\
\hline
\end{tabular}

*t-test: $t-1=$ v.s. Normal control group.

$t-2=$ v.s. AFB1 non-treated group.

$t-3=$ v.s. $A F B_{1}$ Frankincens treated group.

RNA and DNA to total protein ratio \% were found to decrease in the AFB1 non-treated group. However, RNA/DNA ratio \% remained unchanged. Upon treatment with Frankincense RNA/total protein ratio $\%$ returned to its normal but DNA/total protein ratio \% doubled its 
normal value, while upon treatment with Myrrh RNA/total protein ratio did not differ much from AFB1 nontreated group and DNA/total protein ratio \% remained at double its normal value. RNA/DNA ratio \% decreased to almost one-half its normal value on either treatment.

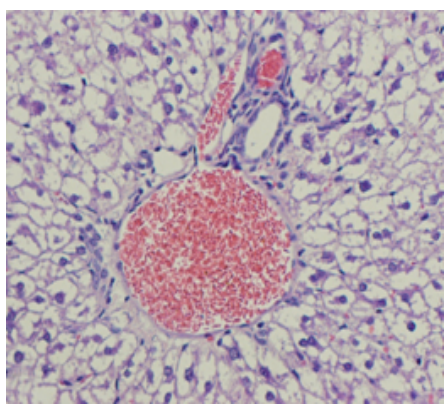

Fig. (1-a)

After treatment with Frankincence, liver sections showed an increase in number of kupffer cells and blood stasis in central and portal veins and swelling bile ducts, with

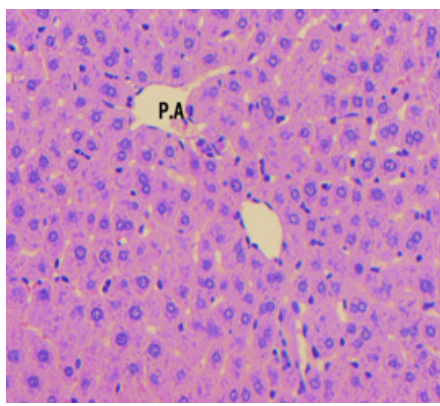

Fig. (2-a)

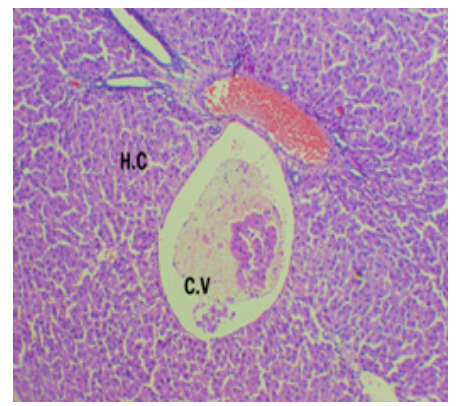

Fig. (2-b)
Treatment with Myrrh, showed dilatation and degenerative of blood vessels, still hepatic focci, (Fig.3-a,
Histological examination of the liver tissue of $\mathrm{AFB}_{1}$ non-treated group showed liver cells without nucleus, degenerative and necrotic with decreased number of kupffer cells, and hemorrhage in the portal area, (Fig.1-a) and hepatoma focci, (Fig. 1b, arrow).

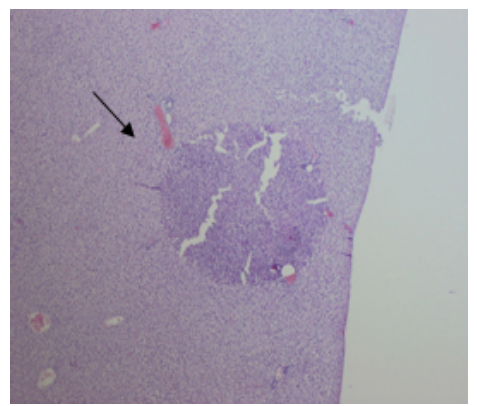

Fig. (1-b)

marked advance in histological composition in portal area (P.A) of hepatic cells (H.C) and central vein (C.V) (Figs. 2-a,b).

arrow), necrotic hepatic cells, central veins and hemorrhage, (Fig. 3-b, arrow). 


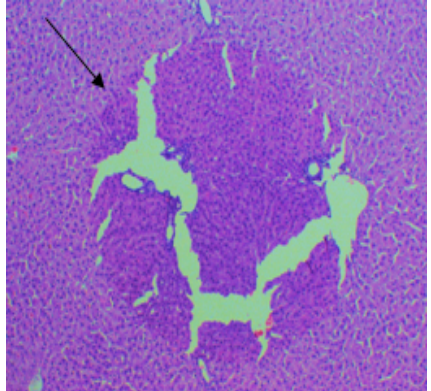

Fig. (3-a)

\section{DISCUSSION}

Primary hepatocellular carcinoma is a major health hazard that might implicate exposure to aflatoxin $\mathrm{B}_{1}$, $\left(\mathrm{AFB}_{1}\right)$, as a food contaminant, (Montalto et al., 2002) ${ }^{\mathbf{1}}$. Chemoprevention colud be achieved with daily foods rich in cancer preventive components, (Vimala et al., 1999 and Borrelli \& Izzo, 2000) $)^{2,3}$ and inhibitory or suppressive agents against carcinogenesis, (Elegbede et al., 2002) ${ }^{4}$.

Both Frankincense, (Gum Olibanum) and Myrrh, (Commiphora merrha), of the family Burseraceae are plant resins used in Arab medicine. The main components of Frankincense are alpha-pinene and boswellic acid, (Hostanska et al., 2002 and Shi et al., 2002) $)^{5,6}$. It is used in the treatment of a variety of malignancies and in treatment of type II diabetes mellitus, (Al-wadi et al., 1991, Liu et al., 2002 and Park et al., 2002) ${ }^{7,8,9}$. Myrrh is rich in sesquiterpenoids and volatile oils, (Zhu et al., 2001 and El Ashry et al., $2003)^{10,11}$. It is used as antiinflammatory, anti- ulcer, antithrombotic, anti-pyretic, anti-septic, anti-hyperlipidemic. It decreases the

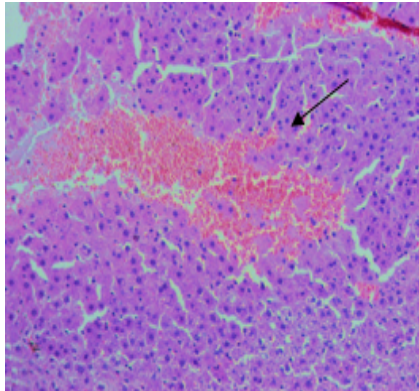

Fig. (3-b)

content of nucleic acids and proteins, (Tariq et al., 1986; Michie \& Cooper, 1991, Al-Harbi et al., 1997, Olajide, 1999 and Massoud et al., 2000) ${ }^{12-16}$. The aim of this esearch was to study the therapeutic value of Frankincense and Myrrh in the recovery of liver after exposure to aflatoxin $\mathrm{B}_{1}$.

It is clear form table (1) that there have been a statistically very highly significant increase in serum GGT, bilirubin and glucose, $(p<0.0001)$ in the $\mathrm{AFB}_{1}$ non-treated group, accompanied by a statistically very highly significant decrease in serum cholesterol and triglycerides, (p $<0.0001$ ), as compared to the normal control group, (t-1) with statistically non-significant changes in all other measured parameters. The increases in serum bilirubin after aflatoxin $B_{1}$ injection could be due to degeneration of RBCs. This is in contradiction with Guerre et al., $1997^{33}$ and Rastogi et al., $2001^{34}$. The decrease in serum lipids and increase in glucose is considered as one of cancer recognition. This agrees with Burt et al., $1981^{35}$ who reported that glucose level was significantly higher due to increased gluconeogenesis. The decrease in triglycerides and cholesterol agrees with Singh and 
Venkitasuburamanian, $1975^{36}$ and Ekman et al., $1982^{37}$. The very highly significant increase in serum GGT is probably due to the degeneration of liver cells as shown by the histopathological examination.

Compared to the normal control group, (t-1) treatment with Frankincense showed a statistically significant decrease in serum bilirubin and an increase of cholesterol to the normal levels which might be due to the high content of boswellic acid in Frankincense with its anti-inflamatory and anti-cancer properties, (Liu et al., 2002) ${ }^{8}$. Serum uric acid significantly increased, $(p<0.05)$, with significant decreased blood hemoglobin, ( $\mathrm{p}<$ 0.005 ) lower value, indicating some amelioration in liver condition. This picture changed a little on treatment with Myrrh, as serum AST and urea appear to be statistically increased, ( $p$ $<0.05$ ). The same applies for serum GGT, with the return of serum uric acid and glucose to their normal vales. which may be due to the increased gluconeogenesis in liver cancer, (Alwadi \& Gumaa, 1987) ${ }^{\mathbf{3 8}}$.

On comparison with $\mathrm{AFB}_{1}$ nontreated group, (t-2), treatment with Frankincense statistically decreased serum bilirubin and blood hemoglobin significantly, $(\mathrm{p}<0.05)$ and serum triglycerides very highly significantly, $(\mathrm{p}<0.0001)$ with a notable increase in serum cholesterol, $(p<0.0001)$, indicating slight amelioration in liver condition.

With Myrrh treatment, serum AST remains higher, $(p<0.01)$ with statistically significantly lower serum bilirubin, $(\mathrm{p}<0.001$ ) which might bedue to the terpens content in the Myrrh which is resistant to the carcenogensis, (Al-Harbi et al., 1994) 39. A decrease in urea, $(p<0.05)$, glucose, $(\mathrm{p}<0.0005)$ and blood hemoglobin, $(\mathrm{p}<0.05)$ was also fond.

On statistical comparison of treatment with Frankincense and Myrrh, (t-3) non-significant differences were found in serum AST, ALT, bilirubin, creatinine and blood hemoglobin, while serum urea, uric acid, cholesterol and glucose were statistically lower and triglycerides higher in the Myrrh treated over the Frankincense treated group, $(\mathrm{p}<0.05-\mathrm{p}<0.0001)$.

Table (2), shows that $\mathrm{AFB}_{1}$ injection had caused a statistically significant, ( $t-1)$ decrease in liver total protein content, ( $\mathrm{p}<0.05$ ) with nonsignificant decrease of both RNA and DNA, as compared to the normal control group. Raju \& Devegowada, $2000^{40}$ and Ekman et al., 1982 attributed this to $\mathrm{AFB}_{1}$ DNA adduct which may interrupt the transcription of RNA necessary for protein synthesis.

Treatment with Frankincense showed a non-significant increase in all measured parameters, while treatment with Myrrh showed statistically significant increase in total protein, ( $\mathrm{p}<0.005)$ and DNA, (p $<0.05$ ) in comparison to the normal control group. Al-Harbi et al., $1994^{37}$ reported significant increases in RNA, total protein, with very highly significant increase in DNA of liver tissues on treatment with Myrrh.

RNA and DNA to total protein ratio \% were found to decrease in the AFB1 non-treated group, paralleling the decrease in total protein with constant RNA/DNA ratio \%. Upon treatment with Frankincense 
RNA/total protein ratio \% returned to its normal, and so did the total protein, but DNA/total protein ratio \% doubled its normal value, which might indicate an increased DNA replication, while upon treatment with Myrrh RNA/total protein ratio did not differ much from AFB1 non-treated group and DNA/total protein ratio \% remained at double its normal value. RNA/DNA ratio \% decreased to almost one-half its normal value on either treatment which might indicate an increased DNA replication in relation to RNA transcription.

However, there has been a statistically non-significant increase, (t-2) in all measured parameters in the Frankincense treated group on comparison to the $\mathrm{AFB}_{1}$ non-treated group, while only a highly significant increase in total protein was observed in the Myrrh treated group on the same comparison, which gives the Myrrh an advantage over Frankincense. Neither Frankincense nor Myrrh showed any statistically significant difference, (t-3) between each other in their effects on the concerned parameters.

Histopathological examination of liver sections of the $\mathrm{AFB}_{1}$ non-treated group showed hepatomic focci, necrotic liver cells and dilatation of blood vessels within central veins and hemorrhage and decrease in the number of kupffer cells. This agrees well with Al-Harbi et al., $1997^{14}$ and Baptista et al., $2002^{\mathbf{4 1}}$.

In conclusion this demonstrated that Frankincense and Myrrh can ameliorate the liver biochemical and histologigal condition after exposure to $\mathrm{AFB}_{1}$.

\section{REFERENCES}

1. Montalto, G., Cervello, M., Giannitrapani, L., Dantona, F., Terranova, A. And Castagnetta, L. A. (2002). Epidemiology, risk factors, and natural history of hepatocellular carcinoma. Ann. NY. Acad. Sci., 963:13-20.

2. Vimala, S., Norhanom, A. W. and Yadav, M. (1999). Antitumor promoter activity in Malysian ginger rhizobia used in traditional medicine. $\mathrm{Br} . \mathrm{J}$. Cancer., 80(1-2):110-6.

3. Borrelli, F. and Izzo, A. A. (2000). The plant kingdom as a sourse of antiulcer remedies. Phytother. Res., 14(8):581-91.

4. Elegbede, J. A. and Gould, $M$. N. (2002). Monotrpenes reduced adducts formation in rats exposed to aflatoxin. Afr. J. Biotech., 1(2): 46-49.

5. Hostanska, K., Daum, G. and Saller, R. (2002). Cytostatic and apoptosis-inducing activity of boswellic acids toward malignant cell lines in vitro. Anticancer. Res., 22(5):2853-62.

6. Shi, S.M., Tian, J.G. and Wang, B.Q. (2002). Study on the detecting methods of the imported medica-olibanum. Zhongguo Zhong Yao Za Zhi, 27(3):170-3.

7. Al-Wadi, F., Fatania, H. and Shamte, U. (1991). The effect of a plant mixture extract on liver gluconeogenesis in streptoztion induced diabetic rats. Diabetes. Res., 18(4):163-8.

8. Liu, J. J., Nilsson, A., Oredsson, S., Badmaev, V., Zhao, W .Z. 
and Duan, R. D. (2002). Boswellic acids trigger apoptosis via a pathway dependent on caspase- activation but independent on fas/fas ligand interaction in colon cancer $\mathrm{H}$ T29 cells. Carcinogenesis., 23(12)2087-93.

9. Park, Y. S., Lee, J. H., Bondar, J., Harwalke, J. A., Safayhi, H. and Golubic, M. (2002). Cytotoxic action of acetyl-11keto-beta-boswellic acid (AKBA) on meningioma cells. Plants. Med., 68(5):397-401.

10. Zhu, N., Kikuzaki, H., Sheng, S., Sang, S., Rafi, M. M., Wang, M., Nakatani, N., Dipaola, R. S., Rosan, R. T. and No, C. T. (2001). Furanosesquiteroenoids of commiphora myrrha. J. Nat. Prod., 64(11):1460-2.

11. El Ashry, E. S., Rashed, N., Salma, O.M. and Saleh, A. (2003). Component, therapeutic value and uses of myrrh. Pharmazie, 58(3):163-8.

12. Tariq, M., Ageel, A. M., AlYhya, M. A., Mossa, J. S., AlSaid, M. S. and Parmar, N. S. (1986). Anti - inflammatory activity of Commiphora molmol. Agents \& Actions., 17(3-4): 3812.

13. Michie, C. A. and Cooper, E. (1991). Frankincese and myrrh as remedies in children. J. R. Soc. Med., 84(10):602-5.

14. Al-Harbi, M. M., Qureshi, S., Raza, M., Ahmed, M. M., Afzal, M. and Shah, A. H. (1997). Gastric antiulcer and cytoprotective effect of Commiphora molmol in rats. J. Ethnopharmacol., 55(2):141-50.
15. Olajide, O. A. (1999). Investigation of the effect of selected medicinal plants on experimental thrombosis. Phytother. Res., 13(3):231-2.

16. Massoud, A. M. and Labib, I. M. (2000). Larvicidal activity of Commphora molmol against Culex pipiens and Aedes caspius larvae. J. Egypt. Soc. Parasitol., 30(1):101-15.

17. Qin, G., Gopalan-Kriczky, P., Su, J., Ning, Y. and Lotlikar, D. P. (1997). Inhibition of aflatoxin B1 induced initiation of hepatocarinogenesis in the rat by green tea. Cancer Lett., 112:149154.

18. Zhou, R., Zhou,Y., Chen, D., Li, S. and Hang, A. (2000). Effects of soaking temperature and soaking time during preparation of water extract of tea on anticlastogenicity against environmental tobacco smoke in the sister-chromatid exchange assay. Toxocology. Letters. 115:23-32.

19. Saris, N. E. (1978). Revised IFCC method for aspartate aminotransferase. Clin. Chem., 24:720-721.

20. Bergmeyer, H. U, Scheibe, P. and Wahlefeld, W.W. (1978). Optimization of methods for aspartate amino transferase and alanine amino transferase. Clin. Chem., 24/1:58-73.

21. Shaw, L. M, Stromme, J. L, London, J. L. and Theodorsen, L, (1983). IFFCC methods for thedetermination of enzymes part 4. IFFCC method for gamma glutamyl transferase [(gammaglutamyl)-peptide; amino acid 
gamma glutamyl transferase, EC 2.3.2.2]. Clinica Chemica Acta., 15F-338F.

22. Jendrassik, $L$. and Grof, $P$. (1938). Vereinfachte photomertische methoden zur bestimmung des blutbilirubin. Biochem., 297:81.

23. Talke, H. and Schubert, G. E. (1965). Enzymatishe Harnstoffbestimmung in Blut und serum in optischen test nach Warburg, Klin Wschr, 41:174.

24. Bulgar, H. M. and Johns, H. E. (1941). The determination of plasma uric acid. J. Biol. Chem., 140:427.Chemical compostion and antioxidant activity of strobiolanthes crispus leaf extract.

25. Larsen, K.( 1972). Creatinine assay by a reaction-kinetic approach. Clin Chem Acta., 41: 209-217.

26. Stadtman, T. C. (1957). Methods in Enzymology, Vol III, colowick, SP, and caplan, NO, (Eds.), Academy Press, New York, NY, PP 392-394,678-681.

27. Rautela, G. S, Hall, R. G, Bekiesz, C. L, Wermus, G. R. (1974). A kinetic method for the rapid and automatic measurement of triglycerides in biological fluids. Clin. Chem., 20:857.

28. Henry, R. J. (1974). Clinical Principles and Technics, Harper and Row, New York, NY, PP 1283.

29. Van Assendelft, O.W. (1970). Spectrophotometry of hemoglobin derivatives, Royal van Gorem Ltd, The Netherlands.

30. Bregman, A.A. (1983). Laboratory investigations and cell biology. New York, Wiley, PP 51-60.

31. Lowry, O.H, Roesebrough, N.S, Farr, A. L. and Randall, R.J. (1951). Protein measurement with folin phenol reagent. J. Biol. Chem., 193:265-275.

32. Bancroft, J.D. and Stevens, A. (1996). Theory and practice of histological technique. $4^{\text {th }}$ Ed. Churchill, Livingston, Edin burgh, London, Melbourne and New York pp50-56.

33. Guerre, P., Burgat, V. and Galtier, P. (1997). Dose-related increase in liver heme catabolism during rabbit of latoxicosis. Toxicol. Lett, 92(2):101-8.

34. Rastogi, R., Srivastara, A. K. and Rostog, A. K. (2001). Biochemocal changes induced in liver and serum of aflatoxin B1treated male wister rats, preventive effect of picroliv. Pharmacol. Toxicol, 88(2):53-8.

35. Burt, M. E., Lowry, S. f., Gorschboth, C. and Brennan, M. F. (1981). Metabolic alterations in noncachectic animal tumor system. Cancer, 47:213846.

36. Singh, N. and Venkitasuburamanian, T. A. (1975). Effect of aflatoxin B1 on lipids of rat tissues. Environ. Pysiol. Biochem, 5(3):147-57.

37. Ekman, L., Korlberg, I., Edstrom, S., Lindmark, L., Scherston, T. And Lundholm, K. (1982). Metabolic alteration in liver, skeletal muscle and fat tissue in response to different tumor burdens in growing sarcoma bearing rats. J. Surg. Res, 33:23-31. 
38. Al-Wadi, F. M. and Gumaa, K. A. (1987). Studies on the activity of individual plants of an antidiabetic plant mixture. Acta. Diabetol. Lat., 24(1):37-41.

39. Al-Harbi, M. M., Qureshi, S., Raza, M., Ahmed, M. M., Giangreco, A. B. and Shah, A.H. (1994). Anticarcinogenic effect of Commiphora molmol on solid tumors induced by Ehrlich carcinoma cells in mice.Chemotherapy., 40(5):33747.

40. Raju, M.V. and Devegowada, G. (2000). Influence of esterified- glucomannan on performance and organ morphology, serum biochemistry and haematology in broilers exposed to individual and combined mycotoxicosis (aflatoxin, ochratoxin and T-2 toxin). Br. Poult. Sci, 41(5):64050.

41. Baptista, A. S., Horii, J., CaloriDomingues, M. A., Glória, E. M., Salgado, J. M. and Vizioli, M. R. (2002). Thermolysed and active yeast to reduce the toxicity of aflatoxin. Sci. agric. (Piracicaba, Braz.), (59) no.2 Piracicaba.

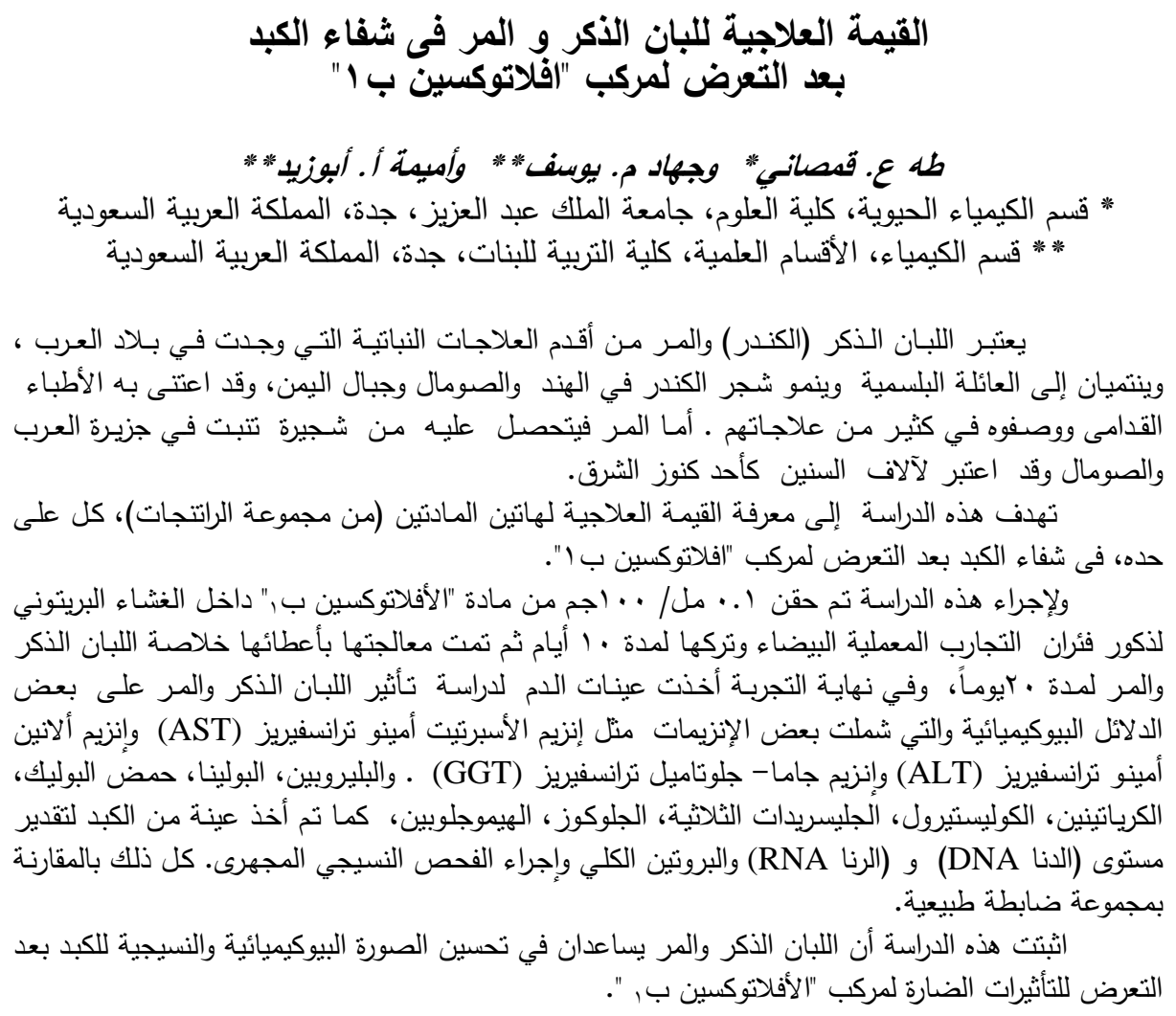

